Gotan, Cletus $\mathrm{T}^{1}$

University of Jos, Nigeria

\title{
A Roman Catholic perspective on Religions AND THE STATE IN SEARCH OF THE COMMON GOOD IN NIGERIA ${ }^{2}$
}

\begin{abstract}
This paper uses "Religion" and "state" interchangeably for church and politics, church and government, and church and civil society. The two are undeniably autonomous and function in different domains, and yet they live in sybiosis, sharing common concerns and interests. The Church's mission is apolitical, but she cannot remain on the sidelines in her prophetic office of relating the Gospel to the practical world of today for the sake of the promotion and salvation of humanity. To arrive at a "Roman Catholic perspective" on the need for cooperation towards the common good, the paper reflects upon specific papal documents, pastoral letters, and episcopal communiqués. Finally, within the current Nigerian context, the fight against increasing poverty and misery, injustice, and the apparent flourishing of the greedy and corrupt, are identified as examples of possible areas for collaboration between church and state.
\end{abstract}

One of the most important social teachings of the Church [from here on "Church" will refer to the Roman Catholic Church] is the encyclical letter of Pope Leo XIII entitled Rerum Novarum, which was published in 1891. The document emphasises the need for just wages and decent working conditions for workers. In 1961, Pope John XXIII expanded on this in another encyclical, Mater et Magistra. In it he deplored the widening gap between rich and poor nations to which he proffered a solution by advocating aid to less developed countries. The Vatican II document Gaudium et Spes (the so-called "Pastoral Constitution on the Church in the Modern World"), issued in 1966, contains elements that express the solidarity of the Church with the whole human family and gives great insight into the Church's commitment to political progress for the sake of the common good. The search for a fair society inspired His Holiness Pope Paul VI’s encyclical Populorum Progressio (“On the Development of Peoples”) in 1967.

1 Cletus Tanimu Gotan is a Professor of Religious Education at the University of Jos, Nigeria.

2 Paper delivered at the Religions and the Common Good in Pluralistic Societies Conference held at the University of Mkar, Benue State, Nigeria from 27-29 August 2007. 
Lending his voice to this social tradition of the Church, Pope John Paul II, in his encyclical entitled Redemptor Hominis (1979), affirmed the existence of great inadequacy in today's economic and political structures. Marking the twentieth anniversary of Populorum Progressio in 1987, the Pope emphasised, in the encyclical Sollicitudo Rei Socialis, the need for the development of humankind and a society that would respect and promote all dimensions of the human person. In his recent encyclical, Deus Caritas Est, the current Holy Father, Pope Benedict XVI, provides a point of departure for this discussion when, in distinguishing between the roles of the Church and state, he asserted that, while the Church does not have a political mission, she nevertheless has a political responsibility. According to the Pontiff,

[t]he Church cannot and must not take upon herself the political battle to bring about the most just society possible. She cannot and must not replace the State. Yet at the same time she cannot and must not remain on the sidelines in the fight for justice. She has to play her part through rational argument and she has to reawaken the spiritual energy without which justice, which always demands sacrifice, cannot prevail and prosper. A just society must be the achievement of politics not of the Church. Yet the promotion of justice through efforts to bring about openness of mind and will to the demands of common good is something which concerns the Church deeply (Benedict XVI 2006:6).

In fact, as one African leader, Mzee Jomo Kenyatta, once noted, the church represents the "moral conscience of a nation, and she is expected to spell out what is good or bad, right or wrong, in the public life of a given community” (quoted by Byrne 1988:85). In 1973, Mwalimu Julius Nyerere, when speaking to Church leaders, also stated that

[u]nless we participate actively in the rebellion against those social structures and economic organisations which condemn people to poverty, humiliation and degradation, the church will become irrelevant to people, and the Christian religion will degenerate into a set of superstitions accepted by the fearful. Unless the church, its members and its organisations, express God's love for people by involvement and leadership in constructive protest against the present conditions of humankind, then it will become identified with injustice and persecution. If this happens, it will die, and humanly speaking deserve to die (Nyerere 1972:1).

The Catholic Bishops' Conference of Nigeria (CBCN) has not been lacking in its contribution towards the spiritual and material progress of Nigeria. Conscious of the fact that the Church "has the right always and everywhere to proclaim moral principles even in respect of the social order, and to make judgements about any human matter in so far as this is required by fundamental human rights or the salvation of souls” (Canon 747, par. 2), the Conference has never minced its words on matters pertaining to the temporal common good or welfare of the people.

In view of its specific role - arising from the commission given to the Church by her founder, Jesus Christ, to be "the light of the world", "the salt of the earth", and "the leaven" of society - the Conference in the past strove to guide, warn, inspire, and nurture the development 
of Nigeria through various pastoral letters and communiqués to enable people to seek human ends and find human fulfilment (cf. Schineller 2002).

\section{THE NIGERIAN CONTEXT TODAY}

Nigeria, the tenth largest country in Africa and inhabited by about 140 million people, became a sovereign state in 1960, having gained independence from Britain. Since then the country has transformed in all facets of development, from three regional governments to a 12-state entity, and later to 36 states and a Federal Capital Territory, Abuja. There are now 774 Local Government Councils in Nigeria, and here, too, different phases of transformation have occurred at different paces.

\section{The religious context}

Judging by external manifestations of religiosity, Nigeria clearly projects the image of a very religious nation. This fact in itself has a positive value which should neither be denied nor underrated. In fact, a countrywide survey, conducted by the British Broadcasting Corporation (BBC) in 2003, described Nigerians as the most religious people in the world. Religion has been one of a few factors that have succeeded in bringing together under one umbrella sizeable numbers of Nigerians, irrespective of their ethnic affiliations. This positive role notwithstanding, it is our national experience that, in the name of religion, a lot of evil has been perpetrated in our society and many crises have arisen, which have devastated the nation and caused untold hardship to many people. Religion has been so politicised, militarised and manipulated by unscrupulous politicians that fraud, rivalry, political antagonism and ethnic discrimination committed behind the mask of "religion" now pose about the greatest threat to national understanding and peaceful co-existence.

In light of the above, it is no wonder religion appears to be one of the problems of our nation rather than a solution to them. The question is, therefore, how can religion have an effective, positive impact on our nation? The problem does not lie with religion in itself, but with the misuse and abuse of religion due to sectional, social, or economic interests, or political ambitions and ethnic considerations.

\section{The social context}

Despite the obvious effects of the earlier "oil boom" in certain places and the fact that there are clear signs of material prosperity in Nigeria, misery seems to be written on the faces of most people as they go about their struggle for survival. Poverty seems to be on the increase, unemployment has reached crisis proportions, and hunger and starvation are now causing havoc among more and more people. In fact, Nigeria must have a very, very high score on any "suffering index" at the moment. According to a World Bank report, "Nigeria presents a paradox: the country is rich, but her people are poor" (cf. Awe 1999). And according to Ali-Akpajiak (2003:2), “Nigeria’s performance in terms of social indicators is increasingly 
and steadily among the worst in sub-Saharan Africa and throughout the developing world”. In none of the development indices, whether with regard to education, health, water, environment, infrastructure, access to justice, maternal/child mortality, etc., does Nigeria achieve a pass mark. The country is among the poorest in the world according to statistics released by the United Nations Development Index. She produces an average of 2.2 million barrels of oil daily and has been able to raise $\$ 320$ billion since 1970, yet evidence shows that these oil dollars have been squandered, mismanaged, or stolen from the country by a corrupt few who have "infected the moral fabric of the society contributing to group rivalries and loss of national direction” (Ali-Akpajiak \& Toni 2003:2, quoting the 1998/1999 report of the United Nations Development Programme (UNDP) for Nigeria). Owing to the deliberate, reckless and persistent manner in which public officials pilfer away the nation's resources, Nigeria has been ranked one of the four most corrupt nations by Transparency International (Ali-Akpajiak \& Toni 2003:12). Finally, according to the World Bank Report, the poor in Nigeria have a cash income that is insufficient to cover minimum standards of food, water, fuel, shelter, medical care and schooling. But what is even more distressing is the fact that Nigerians get poorer with the passage of time and in the same proportion as the national income increases. This is defended by the UNDP in its recent report on Nigeria, which states that "the inescapable picture of Nigeria as one of the poorest countries in the world is not in doubt ... she is worse off today than in the 1980s" (Nigeria 2000/2001 Human Development Report in Ali-Akpajiak \& Toni 2003:6).

\section{Infrastructure}

In terms of infrastructure, Nigeria has been rated among the worst in the world. There are few functional roads, and up to $75 \%$ of Nigerian communities have no access roads. The health system is degenerate, with obsolete equipment and dilapidated hospital buildings. There are enough resources to provide for adequate medical care for Nigerians, but millions die daily of simple preventable diseases. Today, Nigeria has one of the highest maternal and child mortality rates in the whole world. It also has the resources to give all its citizens a free education, but at present, illiteracy is a major challenge; educational facilities have broken down, and the few educated persons are increasingly being lost to the "brain drain". Furthermore, Nigeria has the resources to give its people employment, but millions of school leavers are roaming the streets in search of jobs that do not exist.

It is said that in no country have politicians shown as much contempt for its electorate as in Nigeria. The government lacks the vision and the political will to bring positive change to the lives of the people, who for so long have been wallowing in a pit of poverty, suffering, and want. Citizens also further these anomalies by their permissiveness and their positive disposition to abuse. Their mindset has come to accept suffering and poverty as a way of life. In summary, Nigeria has been described as a society in transition, situated halfway between the traditional world of the pre-capitalist, pre-colonial past, and the modern world of urban life, industry and global communications. 
In a situation such as this, where poverty and misery are on the increase, where injustice is the order of the day, and the corrupt and the greedy seem to be the only successful ones, one wonders if the Church should just keep quiet, watch, pray, and continue to console the victims of the system to humbly accept their suffering with Christian fortitude as they wait for the eternal kingdom of everlasting happiness? The land is no doubt rich and the people intelligent, but it has been stripped bare by a corrupt, selfish, greedy and callous elite (Ehusani 1966:26). There are many without any visible means of earning a livelihood: the orphans, the unprotected, the uncared for, the sick, and the disabled. This situation issues some quite daunting challenges to religious groups in Nigeria.

\section{THE CHURCH AND THE STATE}

The American theologian, H. Richard Niebuhr, who produced a classic work on Christianity and human society, is of the opinion that the question regarding the relationship between the Church and the State is by no means a new one, and that "the problem has been an enduring one through all the Christian centuries” (Niebuhr 1957:2). Difficult as the task may seem, it is absolutely necessary that we recognise the common ground or values shared by the two. State and church undeniably function in different domains, but they also share some concern and common interest.

Without a doubt, the Church is in the world, “[s]he exists in the world, living and acting with it” (Okolo 1991:285). She forms a society in this world composed of men and women, that is, of members of the earthly city who have a call to form the family of God's children during the present history of the human race (Gaudium et Spes, n. 48). She is at once a visible association and a spiritual community, constituted and structured as a society in this world, but primarily on behalf of heavenly values. Her task, in brief, is: "to serve as leaven and as a kind of soul for human society as it is renewed in Christ and transformed into God's family" (Gaudieum et Spes, n. 40). The documents of the Church are clear that its Lord and Saviour, Jesus Christ, gave this Church no specific mission in the political, economic, or social order. The purpose which he set before her is a religious one. However,

[o]ut of this religious mission itself comes a function, a light, and an energy which can serve to structure and consolidate the human community according to the divine law ... [the Church] can and indeed should initiate activities on behalf of all men [sic] especially those designed for the needy, such as the work of mercy and similar undertakings (Gaudium et Spes, n. 2).

A state is a definite entity where law and order are maintained within a defined boundary by a supreme or coercive authority. The basic concern of state is to promote the common good and welfare of its citizens. Its task is to spell out the fundamental values of each community in the temporal sphere, and to provide the community with ways and means to live an honest, just, and peaceful life, combatting all elements of backwardness - lawlessness, poverty, hunger, ignorance, disease, and corruption (Agostino 2001:12). This is achieved through governance, expressed in the institution of the polity. 
It is generally agreed that both Church and state are autonomous and independent societies in their own right, but that they are also complementary to each other in more ways than one. The two are different, but nevertheless linked within the design of God in Christ. They live in a symbiosis (Okolo 1991:285). The point, therefore, is that the mission of the Church is not just spiritual. It is temporal as well and, on this count, the Christian is a citizen of both these worlds.

Both church and state are concerned with the same persons and their actions and relationships - the same persons who are expected to be loyal to both church and state. Many issues touch them both and bind them together - areas of mutual interest that may potentially cause conflict. Issues such as family planning, the sale and use of contraceptives, abortion, euthanasia, bribery and corruption, wages, strikes, housing, unemployment, detention without trial, freedom of speech, the place of religion in education, are of interest to both religion and politics - even if they often disagree on the issues themselves. During his visit to Nigeria, Pope John Paul II (1980:212), speaking to the leaders of government on "our common concern for humanity", declared that, in their own fields, the political community and the Church are autonomous and independent; however, their common concern for humankind brings them together and invites them to collaborate for the welfare of all. The difficulty in the relationship between church and state did not appear when the medieval unity of religion and culture broke down, rendering the spiritual distinct from the temporal, but it has existed since the time of the disciples of Jesus who found it hard to purge their faith in the Son of God from all ideas of a political Messiah. In fact, the prophets again and again bear witness to the failure of the covenant people of God to draw the proper conclusions, with regard to social relations within a nation and between nations, from their belief in the God of Abraham, Isaac and Jacob. This already suggests the blind alleys into which Christians can stray, and have often strayed, when defining that relationship.

One sometimes hears accusations against the Church of it interfering in politics. By this it is often meant that official church spokespersons and personnel, the ordained ministers, are taking political positions or making political statements. Such accusations are more often than not unfounded, and are usually the ranting of those who are uncomfortable with statements made regarding one area of common concern to the Church and politics. While as mother-toall, it is indeed not the mission of the Church to engage in party politics, to sponsor a political party, or to make political choices on behalf of the laity; it remains her duty to identify the objectionable moral elements in the ways governments formulate solutions to problems, and to relate the gospel to the practical world of today.

The Church is a universal moral authority, which exercises her prophetic office in the interest of human promotion and salvation. There is today no quarrel among Christians about the need to order social relations so that justice, freedom, and peace are promoted, and so that human rights are respected. Nyerere, in a categorical statement on the inescapable duty of the church, expressed the view that

[t]he church has to help men rebel against their slums; it has to help them do this in the most effective way it can be done. But most of all the church 
must be obviously and openly fighting all those institutions and power groups, which contribute to the existence and maintenance of the physical and spiritual slums, regardless of the consequence to it or its members ... the church must work with the people in the positive tasks of building a future based on social justice (1972:1).

\section{The basis for the church's involvement in social services}

During His earthly life, our Lord and Saviour, Jesus Christ, went about healing the sick, feeding the hungry, giving sight to the blind, and raising the dead to life. The Church must continue to give witness to Christ by her involvement in humankind's social welfare. This involvement can take different forms depending on those involved, the place and the time, and according to different possibilities available in different situations.

As was seen earlier, since the establishment of the Church in Nigeria, the social well-being of its people has never been forgotten by those who direct her affairs. The first institutions that come to mind are schools and hospitals of various kinds and grades. However, the contribution to the social welfare contribution of Nigerians by the Church also went beyond such visible examples. The preaching of the gospel, with its emphasis on the love of one's neighbour, on justice, on universal brother and sisterhood and on fundamental human rights, could not fail to have an immediate influence on the social sphere in the country. Moreover, the promotion of modern childcare, adult literacy campaigns, premarital training centres, vocational trade schools, and domestic science centres have also been a feature of the Church's efforts.

In the recent past, a greater desire has become visible for control over certain institutions of the Church by government at various levels. In some federal states, this has culminated in "take-overs" - a very emotive word. However, even in the midst of these take-overs, people realise that the Church has a role to play in the social and economic development of the country. No matter, therefore, what institutions or services are taken over by government, the Church retains her duty to show concern for people's social welfare. The Church would not be true to her nature if she retired into the sacristy, and engaged in closed-circuit television of self-entertainment in sacred liturgy, splendidly isolated from the world outside. The Church must refuse to be made to look like an interesting relic from the Middle Ages. All of this means that various members of the Church need to be involved.

Our religions should continue to emphasise and promote the positive involvement of their followers in the betterment of the earthly city. They should share the joys and hopes, the sorrows and anxieties of the people of this age - especially of the poor or of those who are in any way afflicted, and also in Nigeria: a Nigeria of breath-taking economic potential, of salary increases and high prices, extensive oil reserves and other kinds of mineral wealth, a Nigeria of about 140 million people with rich cultural values, but also a Nigeria not immune to materialism, guilty of exploitation of the weak, of mismanagement, challenged by unemployment, the inadequate development of agriculture, the constant failure of water and electricity supply to urban centres, and a Nigeria with an ever-increasing widening of the gap between rich and poor. It is in this Nigeria that the different religious groups are called upon to cooperate with the state in coordinating its social services. 
In his The Gospel to every creature, (Cardinal) Suenens (1963) argued that it is useless to speak to the outcasts of the world about prayer, about heaven and the rest, because they will not listen. According to him one should rather

... speak to them of justice, labour and work with them to obtain indispensable reforms and then Christianity will have some meaning for them. What the poor, humiliated, oppressed and marginalized people are yearning for is a religion that is consoling, reassuring, empowering and promising (Suenens 1963:123).

Some Christian churches are known to have declared the active involvement in politics as a no-go area for their clergy and officials, and rightly so. However, people misunderstand these churches when they want to extend such prohibition to the laity. The lay Christian must not be viewed merely as a non-cleric with a "share” in a church's mission resulting from his or her baptism and confirmation. A fully-fledged Christian lives in the world and obeys the Lord's command to make the world subordinate to Him through their work and their full participation in all the activities of the wider society. This also gives them ample opportunity to demonstrate their Christian values. They, therefore, obey the command to follow Christ - i.e. to sanctify the world - be it as a labourer, housewife, businessman, civil servant, politician, scientist, or whatever. Hence, Christians wishing to follow Christ must not withdraw from the world, merely lamenting its ills, and take refuge in Sunday observance. They must rather commit themselves in the world through their education, skills, and vocational responsibilities to become God's companions in creation. Seclusion from and contempt of the world does not amount to the imitation of Christ; instead, these lead lay Christians away from the path of their duty, even if this has not always been accepted in the history of Christian lay piety.

It is, therefore, not only a sociological but also a theological preposition to say that the lay Christian can sanctify his or her life in the world and not in seclusion from it, and that in so doing he or she can follow Christ. As a Christian, it is one's duty to give substance to one's faith in Christ through one's work - in the world - and to accept the world as one's field of commitment and sanctification. One's occupation, therefore, is not merely a burdensome labour to earn a living; it has to do with creation and salvation.

Religious groups in Nigeria are challenged to be aware of the problems the country faces. They should be aware of bribery and corruption, embezzlement of government and company funds, the growing gap between the rich and the poor, the parade of wealth by many who have it, and many other problems of our contemporary society. Authentic religion cannot be a passive spectator in the unfolding of such events. Its followers should not only ensure that they do not partake in these practices or worsen the situation, but should also find ways, alone and with others, to solve these problems. If a Christian, for example, holds a local, state, or national office; if a Christian is a local councillor, a minister or whatever, he or she must remember it is the duty of every member of the political elite to "wash the feet of one's fellow human beings". The task of such officials is to serve, and they must view their time in office as a time of special responsibility - not towards him or herself, but rather towards the common good. 


\section{SUGGESTIONS TOWARDS LIBERATION AND DEVELOPMENT}

The picture of Nigeria painted above is not a flattering one. What cannot be emphasised strongly enough is that poverty and social ills in Nigeria are humanly-made, by-products of human greed, over-reaching ambition, injustice, classism and structural exploitation. Many Nigerians are simply victims of power struggles and socio-political structures created by the rich and powerful. From this perspective the problem is not poverty as such, but the widening gap between the super-rich and super-poor, the super-powerful and super-powerless; those with and those without property; the job-holders and the jobless, as Nyerere (1972:1), once put it.

The task before the Nigerian state and religions as dictated by life situations of our people should be clear: it is a situation that cries for liberation and for development. And, since development is enhanced by peace, it means that the Nigerian state and the Church have to be committed to peace. Furthermore, since peace is inseparable from justice, it means that the Church and the state must be totally committed to justice.

"I have seen the affliction of my people. I have heard their cry. Indeed, I know their sufferings. I have come to deliver them” (Ex. 3:7). Here we find the reason for Yahweh's leading his people onto the path to liberation. The cries of Nigerians against injustice, exploitation, poverty, artificial inflation, etc., have become impossible not to hear. What is to be struggled against are not just personal, individual sins but social sins, institutionalised sin, sin located in socio-political structures. As Pope Paul VI (1967: n. 47) put it:

It is not just a matter of eliminating hunger, nor even of reducing poverty ... It is a question rather of building a world where every man [sic], no matter what his $[s i c]$ race, religion or nationality, can live a fully human life freed from servitude imposed on him by other men or by natural forces over which he has not sufficient control.

In response to the cry of the people and the call of the Lord, the Church must find the ways and means of guiding the state in such a way as "to bring good news to the poor, to proclaim liberty to captives, and to the blind new sight, to set the downtrodden free, to proclaim the Lord's year of favour” (Lk. 4:18-19). The building of the kingdom of justice and peace is the commission and mandate given by Jesus to his church and followers. This mission calls for conversion on the personal level, a spiritual revolution regarding our behaviour and attitude to life. It also calls for a response at the social level, challenging us to play our part to ensure that truth and justice prevail so that our society can live in peace and tranquillity.

It is also the task of the Church to challenge her members to make faith relevant in action, and to translate the good news within their own milieu. Matthew 25 will then become not simply a bible passage, but a "magna carta” for life: seeing Christ hungry and feeding them, naked and clothing them, thirsty and providing them with a clean water supply, sick and fighting the prevalence of disease with preventive healthcare and good medical service; without shelter and working to provide decent housing for all; seeing them imprisoned and working to make such institutions unnecessary or at least more humane. 
In the extreme circumstances one finds in Nigeria today, pledges, pious admonitions and enunciations of principles for a more egalitarian society are not enough. What is needed is a more prophetic Church endowed with the wisdom that comes from God the Father, equipped with the vision that comes from Jesus Christ the Son, and moved by the passion that comes from the Holy Spirit to intervene in God's name on behalf of our distressed people.

In a country where many professors of political science (for whom democracy is an article of faith), where legal luminaries (who have sworn to defend the rule of law), and even where some respected religious prelates (who are expected to hold truth as sacred), have failed our people, the Church must be the conscience of the nation. It must do so by courageously highlighting the evils in society that constitute the obstacles to peace and prosperity. Many of those whom Nigerians look up to for direction, have become sycophants, praise singers and propagandists for the oppressors of their brothers and sisters. In the face of our nation's distress, religious groups must embark on literacy programmes to cultivate a more discerning citizenry that can discriminate between good and bad leadership and who then can reject bad leadership in the socio-political and economic arena.

When the Church does this, she is not only putting herself at the service of her Lord who is the Light of world and the Salt of the earth, but she is also promoting the kingdom of God here in Nigeria. This is the kind of kingdom which will substitute righteousness for iniquity, truth for falsehood, humility for arrogance, love for hatred, unity for division and holiness for vice. Nigeria needs that kind of a church if our crises of governance are not to become a disaster. Such a church will be an agent which will bring our human community to stand under the judgment of the enduring values of the gospel of Jesus Christ to criticise what is fundamentally inhuman and anti-human in our system of governance. Without such criticism, freedom will continue to yield to totalitarianism, justice will give way to exploitation, charity will recede into ruthlessness, and peace will dissolve into hostility. The church must be a place where all personal and political forces that challenge and undermine the values that constitute the common good are effectively exposed, prophetically denounced, and courageously dismantled.

\section{CONCLUSION}

God has no doubt been kind to the Nigerian nation. He has blessed it with a country of abundant natural resources and a wonderful climate. The Nigerian people are mostly deeply religious and God-fearing, and their ethnic and cultural diversity is a blessing yet to be fully realised. However, all is not well as is shown by the painful difference between the ideals and the realities of our existence. In his message to the CBCN, former President Olusegun Obasanjo said with reference to the problems of corruption, violence, and disunity in Nigeria, that "[t]he Nation is knocking at the door of the Church for peace and harmony at this midnight hour.” And he called upon the Church to "[r]ise up and meet our need!” This is an acknowledgment and invitation to religions to collaborate with government in the search for the common good. It is a call for a self-critical examination of their different roles in and 
duties toward the nation. The "Prayer for Nigeria in distress" composed by the CBCN and recited daily in the Roman Catholic Churches all over the country, seems a fitting prayer with which to end this paper:

All-powerful and merciful Father, you are the God of justice, love and peace. You rule over all the nations of the earth. Power and might are in your hands and no one can withstand you. We praise and thank you, for you are the source of all we have and are. We are sorry for all the sins we have committed and for the good deeds we have failed to do. In your loving forgiveness keep us safe from the punishments we deserve. Lord, we are weighed down not only by uncertainties but also by moral, economic and political problems. Listen to the cries of your people who confidently turn to you. God of infinite goodness, our strength in adversity, our health in weakness, our comfort in sorrow, be merciful to us, your people. Spare this nation, Nigeria, from chaos, anarchy and doom. Bless us with your Kingdom of Justice, Love and Peace. We ask this through Jesus Christ our Lord. Amen.

\section{BIBLIOGRAPHY}

Abbot, W.M. 1966. The documents of Vatican II (Third edition). London: Chapman.

Agostino, T. 2001. Every citizen's handbook: Building a peaceful society. Nairobi: Paulines.

Ali-Akpajiak, S. \& Toni, P. 2003. Measuring poverty in Nigeria. Oxfam Working Paper. Oxford: Oxfam.

Awe, B. 1999. Conflict and divergence: Government and Society. African Studies Review 42(3):1-20.

Ayo, O. 2003. Nigeria slips down Transparency list. [Retrieved 16 June 2007] http://234next.com/ csp/cms/sites/Next/News/5635188-147/

Benedict XVI. 2006. Deus Caritas Est. Nairobi: Paulines.

Byrne, T. 1988. Working for justice and peace: A practical guide. Ndola, Zambia: Mission.

Ehusani, O.G. 1966. A Prophetic Church. Ibadan: Provincial Pastoral Institutes.

John Paul II. 1980. Address to diplomatic corps. Nairobi, 6 May. African Ecclesiastical Review 23(4)(August):212.
Niebuhr, R. 1957. Christ and culture. New York, NY: Harper and Row.

Nyerere, J. 1972. Poverty, Christianity and revolution. Ottawa: Canadian Catholic Conference.

Okolo, B.C. 1991. Social teachings in Gaudium et Spes: The Nigerian connection. In: F.I. Obiora (ed). Catholic Social Teachings En-Route in Africa. Enugu: CIDJAP. 279-294.

Okwara, V.I. 2003. Nigeria: The 1960 flagship on course. Lagos: Petrosini.

Paul VI. 1967. On the development of peoples, no 45. Washington, DC: United States Catholic Conference.

Suenens, L.J. 1963. The Gospel to Every Creature. Westminster: Newman.

Schineller, P. (ed). 2002. The voice of the voiceless. Ibadan: Gaudium et Spes.

KEYWORDs / TREFWOORDE

Nigeria / Nigerië

Church / Kerk

State / Staat

Development / Ontwikkeling

Symbiosis / Simbiose 
Rev. (Prof.) Cletus Gotan

Department of Arts Education

Faculty of Education

University of Jos

NIGERIA

E-mail: cletusgotan@yahoo.com 